International Journal of Current Advanced Research

ISSN: O: 2319-6475, ISSN: P: 2319 - 6505, Impact Factor: SJIF: 5.995

Available Online at www.journalijcar.org

Volume 6; Issue 4; April 2017; Page No. 3284-3286

DOI: http://dx.doi.org/10.24327/ijcar.2017.3286.0249

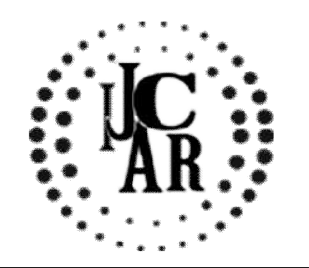

Research Article

\title{
SEX DETERMINATION USING DRY HUMAN SCAPULA
}

\section{Ashwin Kumar S.P and Karpagam}

Saveetha Dental College and Hospitals, P.H. Road, Chennai 77

\begin{tabular}{l}
\hline A R T I C L E I N F O \\
\hline Article History: \\
Received $10^{\text {th }}$ January, 2017 \\
Received in revised form $10^{\text {th }}$ February, 2017 \\
Accepted $14^{\text {th }}$ March, 2017 \\
Published online $28^{\text {th }}$ April, 2017 \\
\end{tabular}

Key words:

Sexual dimorphism

\begin{abstract}
A B S T R A C T
Aim: To determine the sex of the dry human scapulae using formulated criteria.

Objective: To attain a knowledge on the parameters which determine the sex of the dry scapulae.

Background \& Reason: Sexual dimorphism is a key role for forensic anthropology. It allows ascertaining the sex of certain biological discoveries. By postmortem studies it is possible to establish a profile of individuals. This profile allows the identification in cases where bodies are skeletonized. Several bones present dimorphism and have been studied to increase approach for forensic identification. This study will morphometrically evaluate the scapula bone and compare the measurements between scapula bone of female and male cadavers.

Results: The dimensions of the dry male human scapula bone are different from that of the female which will help us to determine the sex.
\end{abstract}

Copyright $₫ 2017$ Ashwin Kumar S.P and Karpagam. This is an open access article distributed under the Creative Commons Attribution License, which permits unrestricted use, distribution, and reproduction in any medium, provided the original work is properly cited.

\section{INTRODUCTION}

In anatomy, the scapula (plural scapulae or scapulas) or shoulder blade is the bone that connects the humerus (upper arm bone) with the clavicle (collar bone). [1]Like their connected bones the scapulae are paired, with the scapula on the left side of the body being roughly a mirror image of the right scapula. In early Roman times, people thought the bone resembled a trowel, a small shovel. The shoulder blade is also called omo in Latin medical terminology. The scapula forms the back of the shoulder girdle. In humans, it is a flat bone, roughly triangular in shape, placed on a posterolateral aspect of the thoracic cage.[2][3]

The scapula is a wide, flat bone lying on the thoracic wall that provides an attachment for three different groups of muscles. The intrinsic muscles of the scapula include the muscles of the rotator cuff-the subscapularis, teres minor, supraspinatus, and infraspinatus.[3]
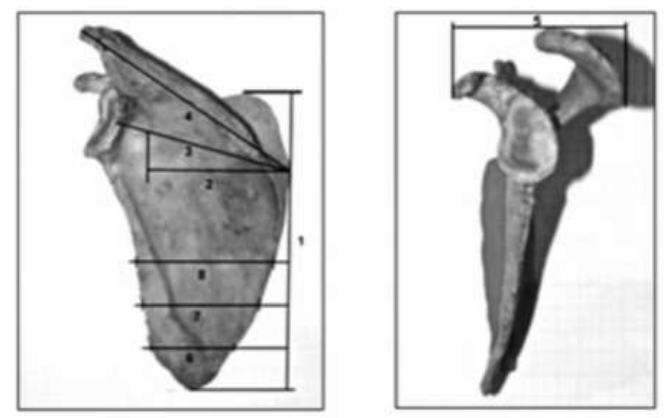

1. Scapula High (SH)

. Distance Betweenbasis and spine (DBSp)

Scapula Width (SW)

4. Spine Width (SpW)

5. Acromion-Coracoid Width (ACW)

6. Scapula Body Width $2 \mathrm{~cm}$ of the lower angle (L2)

7. Scapula Body Width $4 \mathrm{~cm}$ of the lower angle (L4)

8. Scapula Body Width $6 \mathrm{~cm}$ of the lower angle (L6)

Fig. 1. Morphometric parameters evaluated in male and female scapula. 


\section{Surfaces}

\section{Front}

The front of the scapula (also known as the costal or ventral surface) has a broad concavity called the subscapular fossa, to which the subscapularis muscle attaches. The medial two-thirds of the fossa have 3 longitudinal oblique ridges and another thick ridge adjoins the lateral border, which run outward and upward. The ridges give attachment to the tendinous insertions, and the surfaces between them to the fleshy fibers, of the subscapularis muscle. The lateral third of the fossa is smooth and covered by the fibers of this muscle.

\section{Back}

The back of the scapula (also called the dorsal or posterior surface) is arched from above downward, and is subdivided into two unequal parts by the spine of the scapula. The portion above the spine is called the supraspinous fossa, and that below it the infraspinous fossa.

\section{MATERIALS AND METHODS}

The dry human scapula was taken from various medical colleges across Tamilnadu. The height and width of the scapula, height and width of glenoid cavity were used as the parameters for the research.Generally the dimensions of the bone of the man is greater than that of the women due to the way the muscles are attached to the bone and the accommodation of the muscle and the bone. Based on the concept the research was taken and done.

\section{RESULTS}

The averages obtained from the values (in centimeters) of the measures of the scapula were significantly higher in the population of male individuals, as shown in the graph. approximately 50 dry human scapula bones were use $\mathrm{d}$ for the research and measurements were taken.

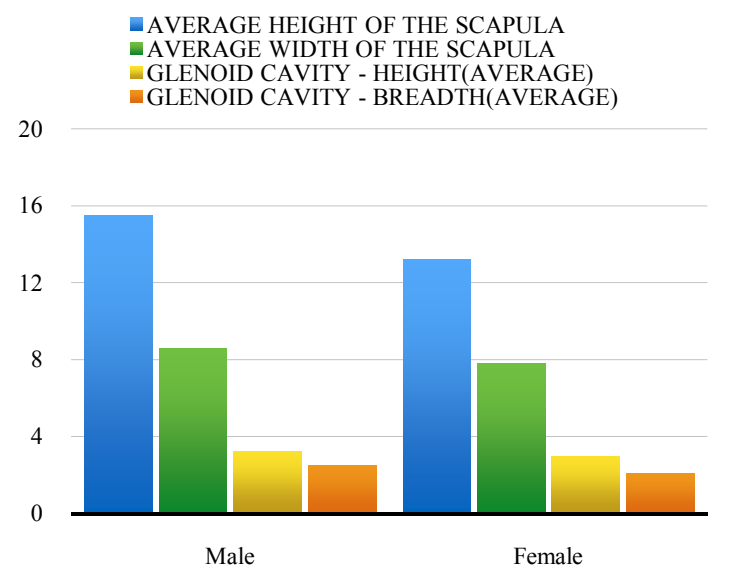

From the total number of readings taken, the average of scapula height $(+/-15.5)$, average width of the scapula $(+/-8.6)$ for male and female were calculated. average of glenoid cavity - height (+/-3.8) and glenoid cavity -

\section{DISCUSSION}

From the above results that is got by measuring the height and width of the scapula bone and the glenoid cavity, it is clear that there are few noticeable differences between the scapula bone of women and men. As the muscularity in men are more stronger than that of the women the dimensions of the scapula bone are as of the above results.

The present study demonstrated higher values of measurements of male compared to female scapula bones. Studies involving the sexual dimorphism in scapula bones still are few when compared to the number of work involving other bones, such as hip bones for example. Using different methodologies several authors have shown that there are significant differences between several bones, including male andfemale scapula bones. Machado et al. using the same morphometric parameters adopted in this study have shown a significant difference between male and female individuals in Individuals with Hispanic descent. These authors obtained values that assert that the less accurate measure between the scapula bones of the two sexes was the width of the spine, while our study found that the most significant difference was between the heights of the scapula. The measure showing the least difference between sexes was the width of the body of the scapula to $6 \mathrm{~cm}$ from the bottom angle in both studies. [12]

\section{CONCLUTION}

From the above data it is clear that the morphology of the male human scapula is different from the female scapula. This helps in sex determination and forensic science. The scapula is a sexually dimorphic bone with high potential for use in forensic purposes. The measurements performed were effective for gender identification also in a mixed population. Another advantage is to contribute to the formation, if possible, of a standard for the population.

Therefore, these data reflect the importance that more studies need to be conducted using this bone as a tool for personal identification. This way the measurements of this bone can be useful in cases where other methods are not applicable, increasing the range of options of forensic investigation teams.

\section{References}

1. Almeida, A. J. \& Costa, J. B. O. Lições de Medicina Legal. 14a ed. São Paulo, Companhia Editora Nacional, 1977.

2. Azevedo, J. M. C. A. A Eficácia dos Métodos de Diagnose Sexual em Antropologia Forense. Tese Mestrado em Medicina Legal e Ciências Forenses. Lisboa, Faculdade de Medicina, Universidade de Lisboa, 2008.

3. Bainbridge, D. \& Genoves, S. T. A study of sex differences in the scapula. J. R. Anthropol. Inst., 86:109-34, 1956.

4. Bruzek, J. \& Murail, P. Methodology and Reliability of Sex Determination from the Skeleton. In: Schmitt, A.; Cunha, E. \& Pinheiro, J. (Eds.). Forensic Anthropology and Medicine: Complementary Sciences from Recovery to Cause of Death. Totowa, Humana Press, 2006. pp. 225-42.

5. Buikstra, J. E. \& Ubelaker, D. H. Standards for Data Collection from Human Skeletal Remains: Proceedings of a Seminar at the Field Museum of Natural History (Arkansas Archeological Report Research Series, Book 45). Fayetteville, Arkansas Archeological Survey, 1994.

6. Oliveira costa, A. C.; Feitosa de Albuquerque, p. P.; de Albuquerque, p. V.; Ribeiro De Oliveira, B. D.; Lima de Albuquerque, Y. M. \& Caiaffo, V. Morphometric analysis of the scapula and their differences between females and males. Int. J. Morphol., 34(3):1164-1168, 2016. 
7. Thaller, Seth; Scott Mcdonald, W (2004-03-23). Facial Trauma. ISBN 978-0-8247-5008-4.

8. "Ossification". Medcyclopaedia. GE.[dead link]

9. "II. Osteology. 6a. 2. The Scapula (Shoulder Blade). Gray, Henry. 1918. Anatomy of the Human Body.".

10. Paine, Russ; Voight, Michael L. (2016-11-22). "THE ROLE OF THE SCAPULA". International Journal of Sports Physical Therapy. 8 (5): 617-629. ISSN 21592896. PMC 3811730. PMID 24175141.
11. Saladin, K (2010). Anatomy \& Physiology. McGrawHill.

12. Machado, M. D.; Corona, S. E. \& Arredondo, A. C. Determina- ción del sexo a partir de la escápula en europoides de ascen- dencia hispánica. Rev. Esp. Antropol. Fis., 32:36-42, 2011.

\section{How to cite this article:}

Ashwin Kumar S.P and Karpagam (2017) ' Sex Determination Using Dry Human Scapula', International Journal of Current Advanced Research, 06(04), pp. 3284-3286.

DOI: http://dx.doi.org/10.24327/ijcar.2017.3286.0249 